\title{
EPISKOPI BLINDNESS*
}

\section{HEREDITARY BLINDNESS IN A GREEK CYPRIOT FAMILY}

\author{
BY \\ P. J. TAYLOR, $\dagger \pm$ T. COATES, $\uparrow$ AND MURIEL L. NEWHOUSE \\ Akrotiri, Cyprus
}

THIs paper describes a familial blindness confined to the male members of one Greek Cypriot family group, most of whom live in Episkopi, a large mixed Greco-Turkish village on the south coast of Cyprus, 10 miles west of Limassol. The village has given its name to the cantonment of the Middle East Headquarters a few miles away.

The family tree was obtained from a series of interviews in the village and in Limassol, some conducted through an interpreter. Four of the children are at present in the Blind School in Nicosia, the fifth being below school age. The adults live either in Episkopi or in Limassol.

\section{Clinical Features}

The family tree (Fig. 1, opposite) extends through six generations in which 16 out of a total of 38 males are affected. The family are aware that the disease is transmitted through the female line to about half the male issue, and a study of the family tree confirms this.

Four of the affected males are dead, and eleven of the remaining twelve have been examined.

Questioning the patients and a superficial examination have uncovered no evidence of other hereditary stigmata, nor is there sign of mental defect; indeed the occupations of the adult affected members range from that of highly capable trilingual telephonists to that of a useless village alcoholic.

The normal pattern of events is that the child's eyes appear normal at birth, although this has not been confirmed by medical examination, and that at about the age of 6 weeks the parents begin to suspect that he is affected. Nine of the eleven examined have followed this pattern and are said to have been blind since birth. Two have proved exceptions to this rule-one who was capable of reading large print with the right eye until the age of 13 , having only perception of light in the left eye. Since that age he has been amaurotic. The other (Case 1), now 3 years old, is able to find his way about the house, using his right eye, and he, too, has only perception of light in the left eye.

Seven cases show a transverse corneal band about $1.5 \mathrm{~mm}$. in breadth, traversing the equator of the cornea and extending well into the substantia propria. In the older patients this lesion is ill-defined, its borders having become fused with a

* Received for publication July 17, 1958.

$\ddagger$ Present address: St. Thomas's Hospital, London. 


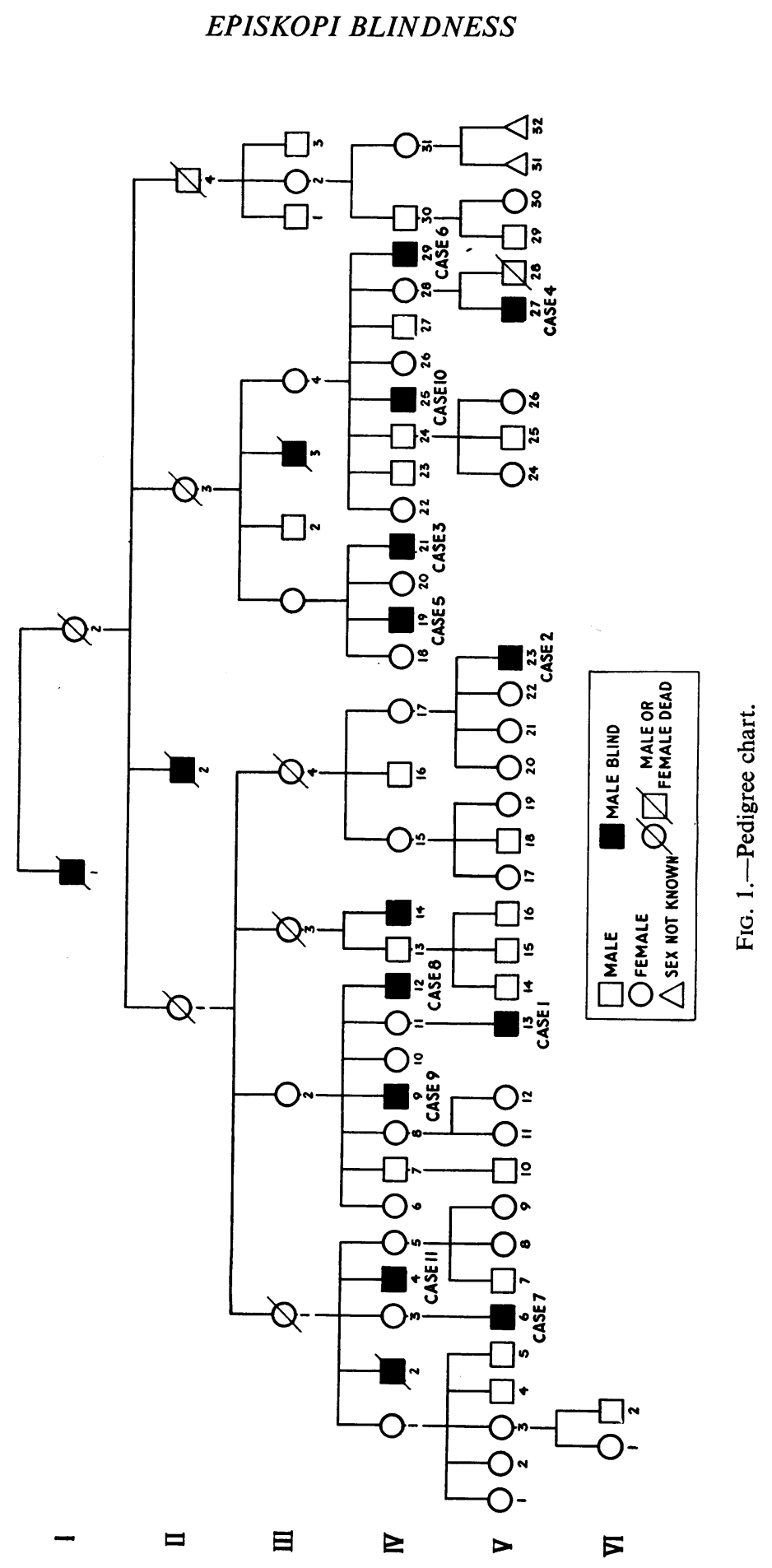


generalized corneal opacity. In the four younger members only one shows this transverse band. The colour ranges from lemon to white in the younger adults and to chalky white in the older adults (Fig. $2 a-c$ ).
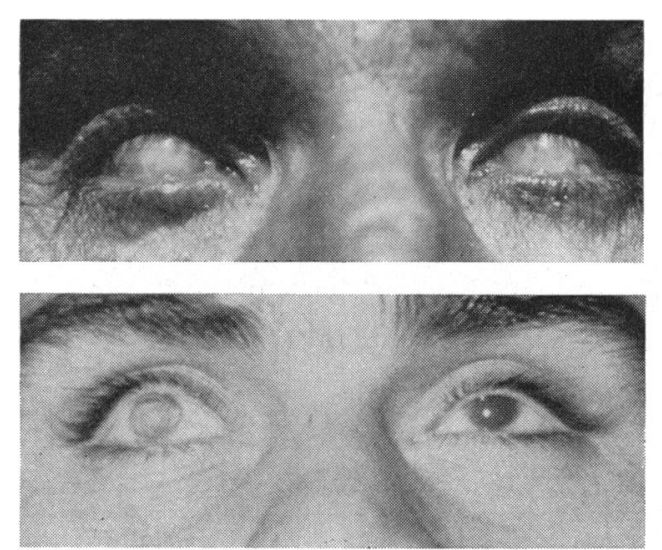

FIG. 2(a) and (b).-Case $7(\mathrm{~V}, 6)$, showing transverse corneal opacity in the right eye in two directions of gaze.

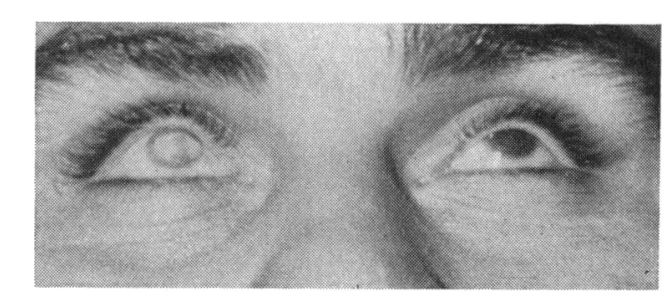

FIG. 2(c).-Case 11 (IV, 4), showing bilateral transverse corneal opacities blending with general opacity.

Only one fundus was partially visible, and this was in the 3-year-old child (Case 1) who still has some vision in the right eye. The right disc was not seen, but the lower half of the retina was already degenerate with diffusely scattered spots of choroidal pigmentation. The left eye showed a retrolental opacity, but a red reflex was visible. In the only other patient with light perception (Case 3), the left eye showed a similar retrolental opacity with a red reflex. The clinical findings are summarized in the Table (opposite).

\section{Discussion}

The pattern of inheritance appears to be that typical of a sex-linked recessive condition such as is seen in haemophilia. One point, however, is probably worthy of note - of the seventeen females who have had male issue, thirteen have transmitted the defect; a higher figure than one would expect from the usual behaviour of a recessive transmission. On the other hand, of the thirty males at risk through their mothers, fifteen are blind- 
TABLE

\section{CLINICAL FINDINGS IN ELEVEN CASES}

SYMPTOMS

\begin{tabular}{|c|c|c|c|c|c|c|c|c|c|c|c|}
\hline $\begin{array}{l}\text { Position } \\
\text { in } \\
\text { Pedigree }\end{array}$ & $\begin{array}{l}\text { Case } \\
\text { No. }\end{array}$ & $\begin{array}{c}\text { Age } \\
\text { (yrs.) }\end{array}$ & Side & $\underset{\text { Eye }}{\text { Small }}$ & $\begin{array}{l}\text { Corneal } \\
\text { Opacity }\end{array}$ & $\begin{array}{c}\text { Transverse } \\
\text { Corneal } \\
\text { Band }\end{array}$ & $\begin{array}{c}\text { Evidence } \\
\text { of } \\
\text { Iritis }\end{array}$ & Cataract & $\begin{array}{c}\text { Retro- } \\
\text { lental } \\
\text { Opacity }\end{array}$ & $\begin{array}{c}\text { Fundus } \\
\text { Reflex }\end{array}$ & Amaurosis \\
\hline \multirow{2}{*}{$\mathrm{V}, 13$} & \multirow{2}{*}{1} & \multirow{2}{*}{3} & $\mathbf{R}$ & & & & & & + & + & Some vision \\
\hline & & & $\mathbf{L}$ & & & & & & + & + & $P$ of $L$ \\
\hline \multirow{2}{*}{$\mathrm{V}, 23$} & \multirow{2}{*}{2} & \multirow{2}{*}{9} & $\mathbf{R}$ & + & + & + & & & & & + \\
\hline & & & $\mathbf{L}$ & + & + & + & + & + & & & + \\
\hline \multirow{2}{*}{ IV, 21} & \multirow{2}{*}{3} & \multirow{2}{*}{9} & $\mathbf{R}$ & & & & & + & & & + \\
\hline & & & $\mathbf{L}$ & & & & & & + & + & $P$ of $L$ \\
\hline \multirow{2}{*}{ V, 27} & \multirow{2}{*}{4} & \multirow{2}{*}{9} & $\mathbf{R}$ & + & + & & & + & & & + \\
\hline & & & $\mathbf{L}$ & & & & + & + & & & + \\
\hline \multirow{2}{*}{ IV, 19} & \multirow{2}{*}{5} & \multirow{2}{*}{12} & $\mathbf{R}$ & + & + & + & & + & & & + \\
\hline & & & $\mathbf{L}$ & + & + & + & & & & & + \\
\hline \multirow{2}{*}{ IV, 29} & \multirow{2}{*}{6} & \multirow{2}{*}{21} & $\mathbf{R}$ & + & + & + & & & & & + \\
\hline & & & $\mathbf{L}$ & + & + & + & & & & & + \\
\hline \multirow{2}{*}{$\mathrm{V}, 6$} & \multirow{2}{*}{7} & \multirow{2}{*}{21} & $\mathbf{R}$ & & + & + & & & & & + \\
\hline & & & $\mathbf{L}$ & & + & & & & & & + \\
\hline \multirow{2}{*}{ IV, 12} & \multirow{2}{*}{8} & \multirow{2}{*}{22} & $\mathbf{R}$ & & + & + & & + & & & + \\
\hline & & & L & + & + & + & & & & & + \\
\hline \multirow{2}{*}{ IV, 9} & \multirow{2}{*}{9} & \multirow{2}{*}{23} & $\mathbf{R}$ & + & & & + & & & & + \\
\hline & & & $\mathbf{L}$ & + & + & & + & & & & + \\
\hline \multirow{2}{*}{ IV, 25} & \multirow{2}{*}{10} & \multirow{2}{*}{31} & $\mathbf{R}$ & + & + & + & & & & & + \\
\hline & & & $\mathbf{L}$ & + & + & + & & & & & + \\
\hline \multirow{2}{*}{ IV, 4} & \multirow{2}{*}{11} & 40 & $\mathbf{R}$ & & + & + & & & & & + \\
\hline & & 40 & $\mathbf{L}$ & & + & + & & & & & + \\
\hline
\end{tabular}

the proportion expected. Not one of the blind males has had children. None is married, and this is believed to be due to prejudice. Indeed, it is said that the girls have some difficulty in finding husbands, although they are attractive and well endowed.

Hereditary eye lesions may affect one or more parts of the anatumy of the eye; they may be present at birth or may appear later. This latter group, sometimes known as the abiotrophies, includes a large range of clinical syndromes, e.g. the corneal dystrophies, cataracts, retrolental lesions, and fundus lesions, such as retinitis pigmentosa and Leber's optic atrophy.

A hereditary transverse band-like corneal opacity has been reported by Streiff and Zwahlen (1946), who described three cases in one sibship, two female and one male, in which this was the only lesion. In our series the opacity was only one feature of what would appear to be a generalized progressive degeneration of the ocular anatomy. We can find no report of a similar disease in the standard text-books of medical ophthalmology. 


\section{Summary}

(1) Six generations of a Greek-Cypriot family with hereditary blindness are described, of whom eleven blind males have been examined.

(2) The pattern of inheritance appears to follow that of a sex-linked recessive condition.

(3) The clinical features are described, a transverse corneal opacity being seen in many of the cases.

(4) All the affected adults are amaurotic.

We wish to thank the Director-General, Royal Air Force Medical Service, and the Director of Medical Services, Cyprus, for permission to publish this communication.

We should like also to thank J. S. Last, Esq., F.S.A., of Episkopi, without whose help this paper might not have been written, and Lt.-col. D. Jagger, R.A.M.C., for advice on the ophthalmology.

\section{REFERENCE}

Streiff, E. B., and ZWAHLEN, P. (1946). Ophthalmologica (Basel), 111, 129. 